\title{
Recruitment and Standing Stocks in Populations of One Green Alga and Five Brown Algae in the Intertidal Zone Near La Jolla, California During 1973-1977
}

\author{
F. C. Gunnill \\ Scripps Institution of Oceanography, A - 008, La Jolla, California 92093, USA
}

\begin{abstract}
For 4 years, populations of Codium fragile, Eisenia arborea, Egregia laevigata, Sargassum muticum, Halidrys dioica and Cystoseira osmundacea were surveyed in $25 \mathrm{~m}^{2}$ permanent quadrats at La Jolla, California, USA. The algae had annual periods of reproduction and recruitment and thus annual standing stock variations. Most species reproduced in winter-spring and/or recruited in spring-summer. Sargassum muticum, however, reproduced in late spring and recruited at the end of summer. For most species, seasonality was adaptive for regional tidal exposure and storm patterns, desiccation, water motion and availability of free space. Populations of several species varied substantially between years; between 1973 and 1977 , standing stocks generally increased for $S$. muticum and $C$. osmundacea and declined for C. fragile, E. laevigata and E. arborea. Within years, the recruitment and standing stocks of each species were generally similar at comparable quadrats. It is reasonable to assume that population fluctuations were caused by regional environmental factors such as cloud cover, air or water temperature and wave action varying during the reproductive and recruitment periods of each species, although no single one of these factors could be identified as predominantly important.
\end{abstract}

\section{INTRODUCTION}

Variations in the recruitment and standing stocks of plant and animal populations are fundamentally important in both pure and applied ecology. Such phenomena have been relatively little studied for marine macroalgae (Chapman, 1979). Populations of several laminarian and fucoid algae have fluctuated over relatively long periods of study (Walker, 1956; Fischer-Piette and Duperier, 1960; North, 1971). Longterm population declines of other algae have been attributed to stresses from pollution (Bellamy et al., 1967; Widdowson, 1971) or human interference (Boalch et al., 1974). Comparisons of populations studied over long time periods have been complicated by natural population variations with shorter periods (cf. Wilkinson and Tittley, 1979).

Macroalgae often have annual periods of reproduction, recruitment and growth. Changes in the abundance of algal species can separate summer and winter floras into different communities (Hruby, 1975). Such seasonality often has been regarded as an adaptation to factors limiting (or triggering) growth (Conover,
1964; Edwards, 1969; Jackson, 1977). Growth-limiting factors can interact with desiccation (Jenik and Lawson, 1967) and disturbance (Dayton, 1971; Santelices, 1977 ) to cause variations in standing stocks. Quantifications of such variations in recruitment or standing stocks and especially correlations with specific antecedent environmental events have been infrequent (Doty, 1971; Lewis, 1977).

The present 4 -year study quantifies the recruitment and standing stocks of individuals of 6 perennial macroalgae. The algae were surveyed at 13 permanent intertidal quadrats at 2 protected outer coastal locations near San Diego, California. Annual standing stock variations and, for some species, their differences with tidal level and topography are described. In addition, records of fluctuations in environmental factors are summarized and related to the reproduction and recruitment of the algal populations.

\section{MATERIALS AND METHODS}

Thirteen $25 \mathrm{~m}^{2}$ quadrats covering the entire tidal ranges of 6 species of macroalgae (Table 1) were map- 
Table 1. Taxonomic relationship, tidal ranges and geographic distributions of the algae studied at La Jolla, California

\begin{tabular}{|c|c|c|c|c|}
\hline & $\begin{array}{l}\text { Annual } \\
\text { fronds }\end{array}$ & $\begin{array}{l}\text { Gameto- } \\
\text { phyte }\end{array}$ & $\begin{array}{l}\text { Tidal range } \\
\text { at La Jolla }\end{array}$ & $\begin{array}{l}\text { Geographic range } \\
\text { on Pacific Coast }\end{array}$ \\
\hline \multicolumn{5}{|l|}{ Chlorophyta } \\
\hline \multicolumn{5}{|l|}{ Siphonales; Codiacea } \\
\hline Codium fragile (Suringar) Hariot & No & No & -1 to $+4 \mathrm{ft}$ & Alaska - Baja California $\cdots$ \\
\hline \multicolumn{5}{|l|}{ Phaeophyta } \\
\hline Egregia laevigata Setchell & No & Yes & -2 to +1 & $\begin{array}{l}\text { Central California - } \\
\text { Central Baja California...... }\end{array}$ \\
\hline Eisenia arborea Areschoug & No & Yes & -2 to $+6^{\bullet}$ & $\begin{array}{l}\text { Central California - } \\
\text { Central Baja California ... . }\end{array}$ \\
\hline \multicolumn{5}{|l|}{ Fucales; Sargassceae } \\
\hline Sargassum muticum (Yendo) Fensholt & Yes & No & -2 to $+6^{*}$ & $\begin{array}{l}\text { British Columbia - } \\
\text { Gulf of California ..... }\end{array}$ \\
\hline Cystoseira osmundacea (Menzies) C.A. Agardh & Yes & No & -2 to +1 & $\begin{array}{l}\text { Oregon - } \\
\text { North Baja California... }\end{array}$ \\
\hline Halidrys dioica (Gardner) & Yes & No & -2 to +1 & $\begin{array}{l}\text { North. California - } \\
\text { South. California } \cdots\end{array}$ \\
\hline \multicolumn{5}{|c|}{$\begin{array}{l}\therefore \text { includes pools; without pools } E \text {. arborea }-2 \text { to }+1 \mathrm{ft} \text { and } S \text {. muticum generally }-1 \text { to }+3 \mathrm{ft}(1 \mathrm{ft}=0.33 \mathrm{~m}) \\
\ldots \text { pocket distributions from Northern California to British Columbia } \\
\text {... Abbott and North (1971) } \\
\text { Gardner (1913) }\end{array}$} \\
\hline
\end{tabular}

ped between August and November 1973. The quadrats were censused fortnightly for 2 years and then at longer intervals, generally monthly, until November 1977. Each new individual and the presence or absence of each older one were recorded on copies of the field maps during each census. Recruitment and standing stock records were tabulated directly from these maps. Data for all species surveyed in all quadrats are given in Gunnill (1979); however, the present paper omits most data from quadrats in which a species was rare (usually $<5$ individuals quadrat ${ }^{-1}$ ).

Records of major environmental factors, presented in Gunnill (1979), are summarized in the present study for comparison with algal standing stocks. The tidal cycle data were taken from U.S. Department of Commerce Tide Tables (Anon., 1975). The movement of rocks, deposition of sand, and the cover by and composition of coralline algal-rhodophyte assemblages were recorded within the quadrats during surveys. Daily environmental records (maximum and minimum air temperatures, water temperature, swell and wave hight and frequency, rainfall, and fog and/or cloud cover) were made on Scripps Pier only a few km distant from the study sites (Fig. 1).

\section{The Algae}

La Jolla is located toward the southern end of the geographical ranges of most species studied (Table 1).
The 2 algae with the widest geographical ranges, Codium fragile and Sargassum muticum, are also predominantly intertidal species. Another algae, studied at La Jolla (Gunnill, 1979), the fucoid Pelvetia fastigiata (Fucales; Fucaceae), is also a widely distributed intertidal species. Two sargassacean algae and both laminarian algae are distributed over a low-intertidal and shallow subtidal range.

Individuals of all 6 species can be perennial within the study locations. However, the only perennial part of a sargassacean alga is the basal system consisting of the holdfast and juvenile fronds. Entire fronds are lost after reproduction: Sargassum muticum loses most of its thallus, whereas Halidrys dioica and Cystoseira osmundacea retain many juvenile fronds. In addition, epiphytes grow on the annual fronds of $S$. muticum just before and as they are lost (e. g. Fletcher and Fletcher, 1975). Each year juvenile fronds elongate and then develop receptacles over relatively long periods of time (Moss and Lacey, 1963; Jephson and Gray, 1977).

Four of the 6 species had relatively simple life cycles for algae; diploid plants released gametes which formed zygotes and grew directly into diploid plants. The 2 laminarian algae had an alternation of generations in which diploid sporophytes released spores which formed microscopic haploid gametophytes. The gametophytes then formed gametes which united and grew into diploid sporophytes. The present study examined only macroscopic plants of each species. 
Recruits, therefore, were 1 to $3 \mathrm{~cm}$ long individuals of the macrothallus generation. Recruits of most species would have been recorded within a few weeks of their initial growth from embryos. Because the juveniles initially resembled each other and not the adults of their species (Neushul, 1972; Black, 1974), an operational taxonomic unit was erected for juvenile laminarian algae. Individuals were withdrawn from the unit when they became identifiable to species. Egregia laevigata (and the rare Macrocystis pyrifera) often became distinct relatively rapidly, but Eisenia arborea (and rare Laminaria species) remained indistinct for considerable periods of time. For laminarians, losses of juveniles were either real losses or transfers to adult status; individuals remaining in the juvenile unit failed to achieve adult morphology. Halidrys dioica and Cystoseira osmundacea are not separated in this study; $C$. osmundacea itself is the most abundant of several Cystoseira species in Southern California. The species cannot be distinguished until individuals develop receptacles when 2 or more years old.

\section{Study Areas}

This study was conducted at 2 locations on opposite sides of a promontory ending in Point La Jolla (Fig. 1). Bird Rock (BR) was situated to the South and Devil's Slide (DS) to the North of the promontory. Both were

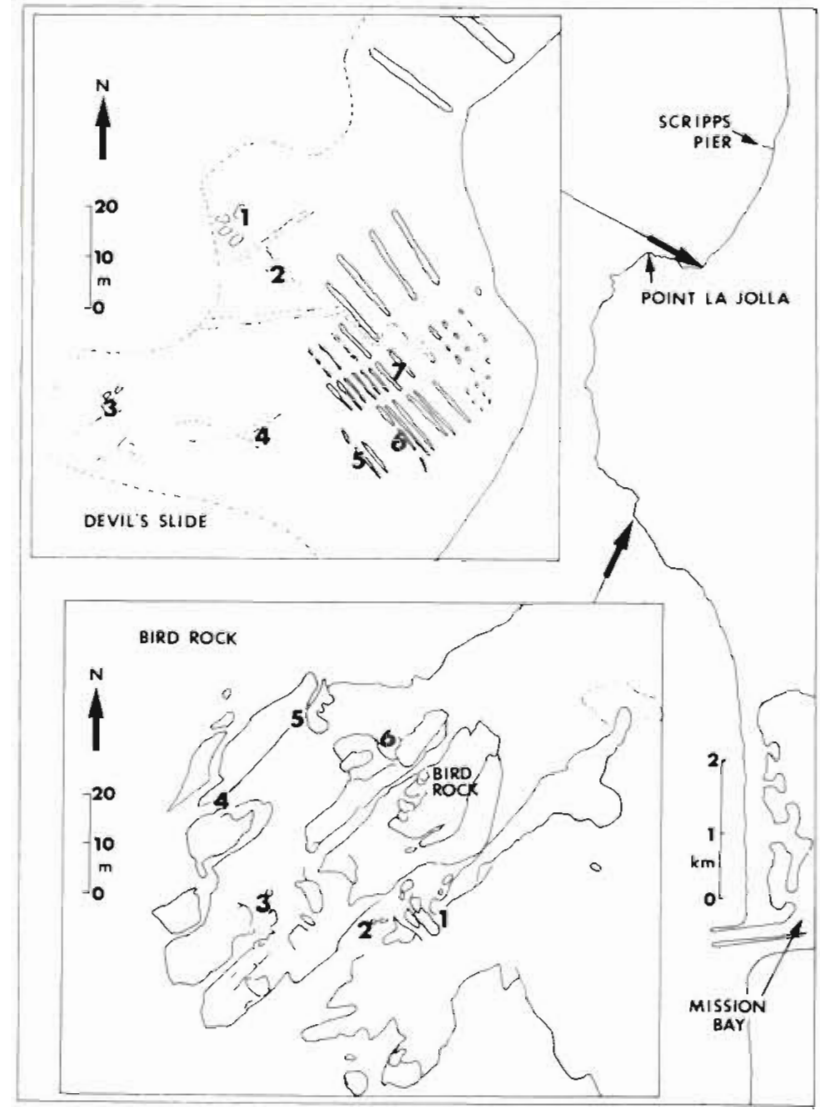

Fig. 1. Locations of study areas and quadrats

Table 2. Topography of survey quadrats represented as percentages of surface area when viewed from above. Outcrops extend 0-2 and ridges $2-4 \mathrm{ft}$ above the platform; depressions lie $0-0.2 \mathrm{ft}$ below the platform. Shallow and deep (") pools or channels extend $0-1$ and $1-3 \mathrm{ft}$ below the local platform, respectively. Troughs do not have distinct margins. $(1 \mathrm{ft}=0.33 \mathrm{~m})$

\begin{tabular}{|c|c|c|c|c|c|c|c|}
\hline Devil's Slide Quadrat & 1 & 2 & 3 & 4 & 5 & 6 & 7 \\
\hline & \multicolumn{7}{|c|}{ Percent surface area } \\
\hline Ridges & . & . & . & & 19.4 & 23.5 & 13.6 \\
\hline Outcrops & & & 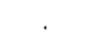 & 1.0 & . & . & . \\
\hline Platform & 18.6 & 74.1 & 56.9 & 53.0 & 32.7 & 74.8 & 45.7 \\
\hline Depressions & . & . & . & . & 7.9 & 1.8 & . \\
\hline Shallow troughs & . & 4.2 & - & & & . & 34.1 \\
\hline Channels & $62.2^{\bullet}$ & 17.6 & $33.7^{\circ}$ & 39.7 & . & . & . \\
\hline Channel margins & 9.5 & 2.9 & 6.1 & & . & . & . \\
\hline Channel rocks & 9.8 & 1.1 & 3.3 & 6.3 & . & . & 6.6 \\
\hline \multirow[t]{2}{*}{ Bird Rock Quadrat } & 1 & 2 & 3 & 4 & 5 & 6 & \\
\hline & \multicolumn{7}{|c|}{ Percent surface агеа } \\
\hline Pools in ridges & 0.2 & . & . & . & & $2.4^{*}$ & \\
\hline Ridges & 26.5 & . & & . & 3.8 & 36.0 & \\
\hline Outcrops & 15.7 & . & . & . & 3.7 & 5.5 & \\
\hline Platform & 29.3 & 9.2 & 74.7 & 70.7 & 78.0 & 51.0 & \\
\hline Pools & 25.8 & . & $6.8^{\circ}$ & $4.1^{\circ}$ & & . & \\
\hline Depressions & . & . & 0.9 & . & . & 4.5 & \\
\hline Troughs & . & 52.5 & & . & 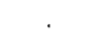 & . & \\
\hline Channels & 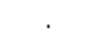 & . & $8.3^{\circ}$ & $21.7^{\circ}$ & $8.5^{\circ}$ & $0.6^{*}$ & \\
\hline Channel margins & 1.2 & 0.6 & 6.7 & 1.2 & 3.7 & . & \\
\hline Channel rocks & . & 28.6 & 2.6 & 2.5 & . & . & \\
\hline
\end{tabular}


protected coastal locations, but because of wave dispersion by submarine canyons, DS was generally a lower energy environment than $\mathrm{BR}$. The 6 quadrats at $\mathrm{BR}$ were distributed over a small peninsula. The 7 quadrats at DS were located on a wide intertidal shelf with series of parallel ridges lying nearly perpendicular to the local shore. All 13 quadrats were representative of similar areas within the locations, but were chosen for their potential to include large numbers of individual algae.

Most of the intertidal area at both locations was a coralline algal-covered hard rock erosional platform rising from lower mid-intertidal $(0$ to $+1 \mathrm{ft}$; 0 to $+0.33 \mathrm{~m}$ ) to mid-tide levels $(+2$ to $+3 \mathrm{ft} ;+0.66$ to $0.99 \mathrm{~m}$ ). The algae studied typically grew on topographic features which interrupted the platforms at each quadrat (Table 2). The features included outcrops and ridges rising above the platforms, broad shallow troughs plus shallow or deep steep-sided channels. Several quadrats included shallow depressions or pools which temporarily retarded drainage. Deep, permanent tidepools were not common in either location but were included in portions of 3 quadrats at $B R$ (Table 2).

\section{RESULTS}

\section{Standing Stocks and Recruitment of Codium fragile}

Individuals of Codium fragile were found throughout the study locations, usually in small, widely sepa- rated areas. This alga generally grew on steeply sloped surfaces, often in association with coralline algae. Large plants most commonly grew alone on inclined portions of large rocks between 0 and $+1.5 \mathrm{ft}$ ( 0 and $+0.5 \mathrm{~m})$, whereas smaller individuals often were abundant on channel margins and ridges. Plants in several survey quadrats predominantly inhabited rocks (BR 2 and DS 1) and/or channel margins (BR 4 and DS 2). Individuals in 4 quadrats inhabited ridges 2 to $4 \mathrm{ft}(0.66$ to $1.32 \mathrm{~m})$ above Mean Lower Low Water (BR 6 and DS 5, 6, and 7).

Standing stocks of Codium fragile were greatest from August to October and were lowest in March and April (Fig. 2). Quadrat populations of more dispersed large individuals at lower tidal levels had both lower maximal and higher minimal abundances than ridge populations, in which few individuals were perennial. Although abundances started to decline in the fall, new growth was noted as late as January. Most losses were individuals torn from their holdfasts. Although some blanched individuals were observed between November and April, such blanching can indicate not death but reproduction. Late spring recruitment on rocks bared in late November indicates that $C$. fragile did reproduce in the winter-spring concurrently with thallus blanching.

Recruitment began around May and continued through the summer into November (Fig. 2). The recruitment of new individuals and the regeneration of known individuals occurred simultaneously within locations. Since most individuals grew near or at formerly occupied positions, some recruits may have

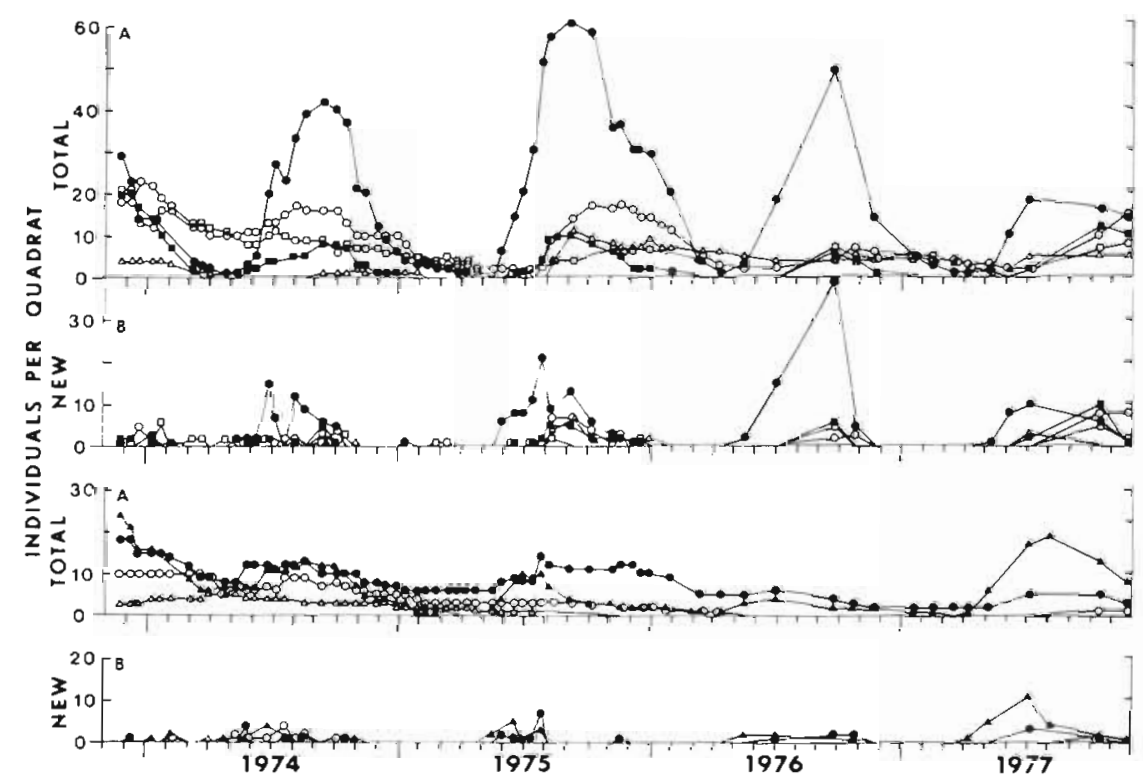

Fig. 2. Codium fragile. Standing stocks (A) and recruitment (B). Top: Ridge quadrats - solid squares, BR 1; solid circles, BR 6; open circles, DS 5; open triangle, DS 6; open square, DS 7. Bottorn: Other quadrats - closed circle, BR 2; closed triangle, BR 4; open triangle, DS 1; open circle, DS 2 
regenerated from portions of plants obscured under coralline algae. However, such apparent regenerations often occurred after lapses of more than a year; thus it was assumed that the majority of recruits were new individuals.

Substantial recruitment occurred from late June into October and thus encompassed longer time spans than the quadrat population peaks. Net recruitment did not occur at DS in the spring; therefore, standing stocks of Codium fragile there frequently increased later in the summer than at BR. The recruitment times of distinctly new individuals also differed between locations; from May to July extending into September at BR and generally from July to September extending into November at DS.

Maximum annual standing stocks of Codium fragile declined from 1973 to 1976 (Fig. 2). Quadrat populations at lower tidal levels declined more strikingly than the highly seasonal ridge populations. Both the recruitment and survival of individuals were low at most quadrats in 1976. However, at one ridge quadrat a fourth successive strong peak in standing stock occurred in 1976 and was followed by a single reduced abundance peak in 1977. Abundances of $C$. fragile generally increased in 1977.

\section{Recruitment and Standing Stocks of Sargassacean Algae}

Three species in the family Sargassaceae grew in at least some of the quadrats surveyed. Cystoseira osmundacea and Halidrys dioica were patchily distributed in low?r intertidal-subtidal areas. Although individuals of the 2 species grew in 8 of the 13 quadrats, they were persistent and/or abundant in only 2 quadrats. Most individuals grew in sheltered locations and were exposed only during relatively low tides.
Sargassum muticum, a native of Japan, colonized the La Jolla area shortly before this study began. It became widely distributed at both study locations and individuals grew from subtidal to high-intertidal levels.

Recruitment by Cystoseira osmundacea plus Halidrys dioica was recorded through the year, but November to February and May to August were peak periods (Fig. 3). The recruitment peaks coincided with reproduction by the same species. Halidrys dioica generally bore enlarged receptacles between March and July. The receptacles developed from February to May in 1975 and from April to July in 1977. C. osmundacea plants with enlarged receptacles were recorded between November and January 1976-1977 and, from January into February in 1975; however, in 1973 individuals were observed releasing gametes in late September. Recruitment was prolonged in the winter of 1974-1975, but recruitment peaks occurred in December 1975, January 1974 and February 1977. Thus in some years reproduction did precede recruitment. The slowly growing juveniles, however, should have originated in the previous reproductive period (Moss and Lacey, 1963; Moss and Sheader, 1973; Gunnill, 1979).

The most substantial quadrat population of $C y s$ toseira osmundacea plus Halidrys dioica at the beginning of the study (DS 1) increased to 12 times its initial magnitude (Fig. 3). At the same time, the smaller quadrat population at DS 2 remained relatively constant and populations did not develop in other quadrats. Both species recruited in quadrats DS 1 and DS 2 in 1974 and 1975. During 1976 net recruitment was low and C. osmundacea did not recruit at DS 2. Recruitment by $C$. osmundacea at DS 1 in 1977 was very conspicuous. Although the abundances of both species increased at DS 1 over the 4 years, much of the net increase arose from recruitment of $C$. osmundacea in 1974 and 1977.

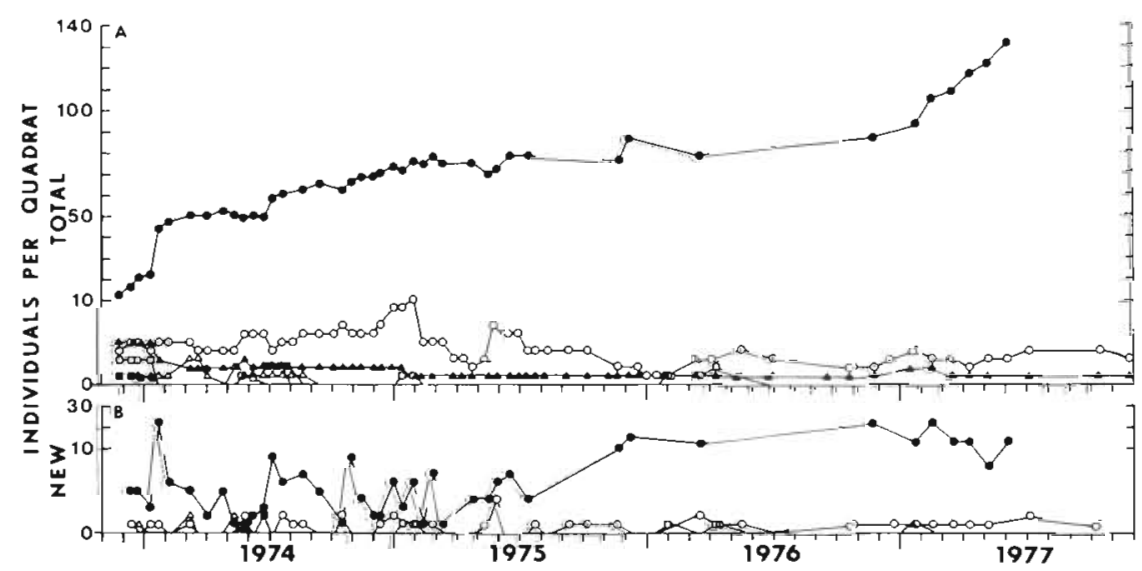

Fig. 3. Cystoseira osmundacea plus Halidrys dioica. Standing stocks (A) and recruitment of new individuals (B) within permanent quadrats. Quadrat symbols: closed circles, DS 1; open circles, DS 2; open triangles, DS 3; open squares, DS 4; closed triangles, BR 2; closed squares, BR 3 
The recruitment of new individuals of Sargassum muticum in September/October caused a substantial increase in standing stocks each year (Fig. 4). Reproduction was centered on May and completed in June. Gamete bearing plants were collected between April and late May, while epiphytes grew on the annual fronds in May and June. Coarse elongate fronds persisted into July in 1975 and 1977 , but generally, for $S$ muticum only bases lacking thalli were present from July to September. Both recruits and older individuals grew and/or regenerated in the fall and winter. Recruitment recorded at these times represented new growth by previously obscured individuals. The accumulation of regenerating individuals caused a second standing stock peak around December (Fig. 4).

Although losses of thalli from bases frequently coincided with small reductions in standing stocks of Sargassum muticum around June, the major declines occurred during the fall and winter (Fig. 4). Individuals exposed on bare rocks above approximately $+1.5 \mathrm{ft}$ $(+0.5 \mathrm{~m})$ and on coralline algal-covered platforms generally died soon after recruitment, while plants in high-intertidal pools or shallow mid-intertidal drainage pools and channels persisted. Except for occasional resurgences, individuals living above lower mid-intertidal levels remained relatively short until April. Older individuals in lower mid-intertidal troughs and channels (e. g. BR 2) grew in the fall and winter. These plants became longer (to $3 \mathrm{~m}$ ) and denser until entire channels were covered by $S$. muticum in the spring

The major increases in the standing stocks of Sargassum muticum occurred between 1973 and 1975 (Fig. 4). Between 1975 and 1977 many quadrat populations apparently reached equilibrium abundances. At some quadrats, individuals of $S$. muticum were rare or absent, evidently due to the lack of suitable habitat. Stations with narrow channels (BR 4, DS 2, DS 4, but not BR 5) or more extensive broad channels (BR 3, DS 1 and DS 3) had similar numbers of $S$. muticum. Most individuals in these quadrats grew on channel margins or rocks and not on the bottoms of narrow deep channels. This alga became most abundant in wide flatbottomed troughs (BR 2, DS 7) or shallow drainage pools (BR 1). At quadrats DS 7 and BR 1 in particular, sand was commonly deposited on or among the rock surfaces occupied by the alga; dense plant growth plus sand and rock motion led to the discontinuation of records at DS 7. In general, S. muticum colonized unstable, mid-intertidal substrates.

\section{Recruitment and Standing Stocks of Laminarian Algae}

Two laminarian algae were common in the survey quadrats: Egregia laevigata was more abundant at DS while Eisenia arborea was more abundant at BR. Perennial individuals of $E$. laevigata were most abundant in wide but not necessarily deep channels (BR 2, DS 1, DS 2, and DS 3). A few perennial individuals of E. arborea inhabited deep permanent pools (BR 3 and BR 6), but most inhabited low intertidal areas (BR 2 and 3). Although some individuals survived for years, as in Black's (1974) study, most individuals died annually. Standing stocks of each species fluctuated in parallel among all quadrats as juveniles colonized the same locations, usually rock or channel edges, each year.

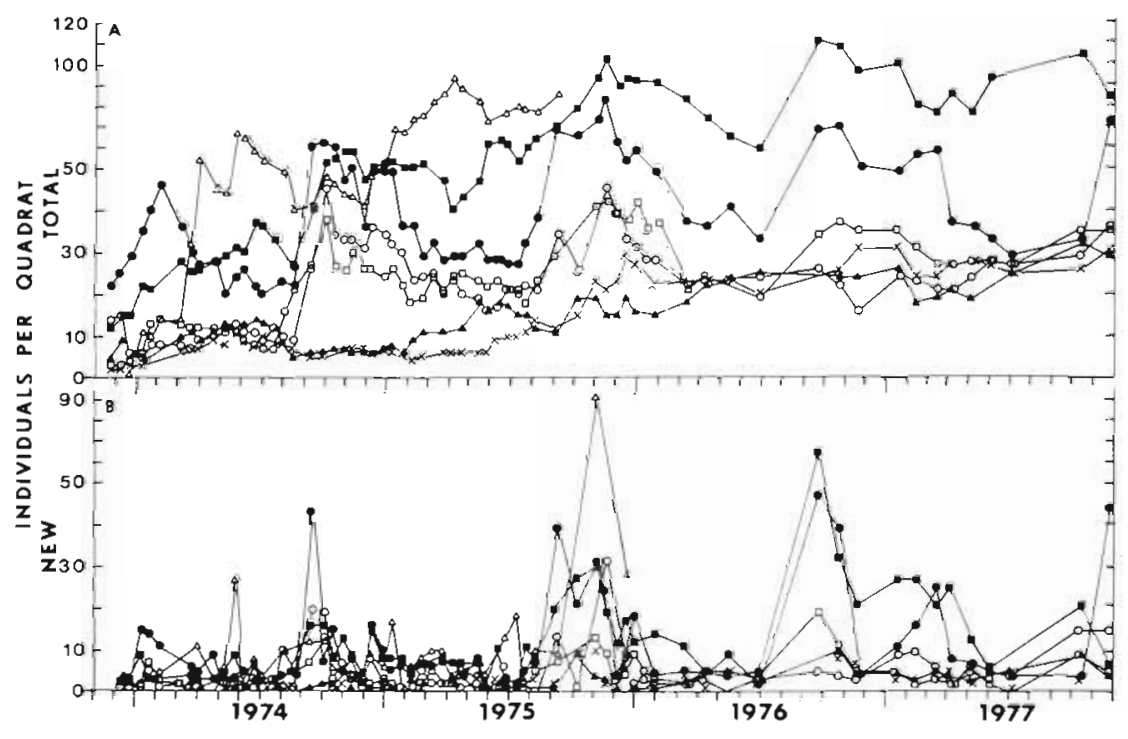

Fig. 4. Sargassum muticum. Standing stocks (A) and recruitment (B) within quadrats. Quadrat symbols: closed circles, BR 1; closed squares, BR 2; closed triangles, BR 3; x, BR 4, open circles, DS 2; open squares, DS 4; open triangles, DS 7 


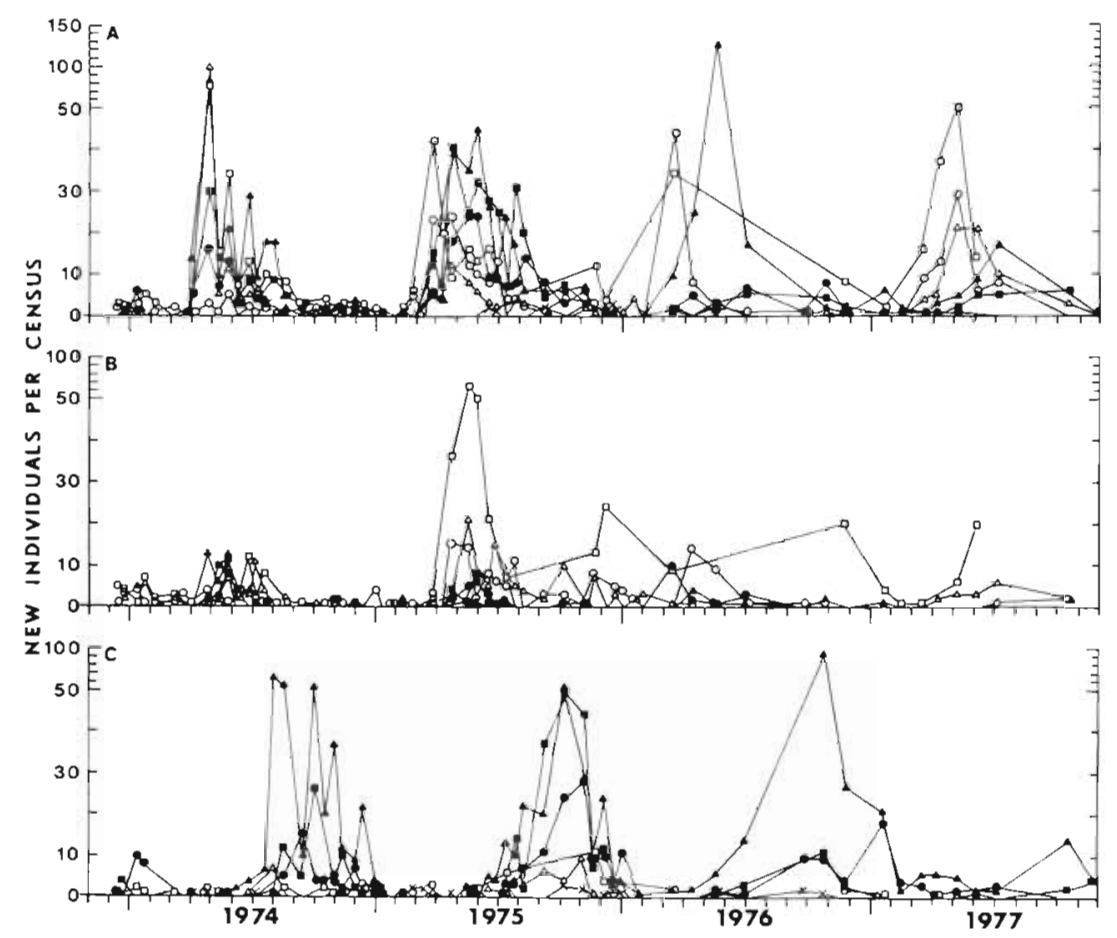

Fig. 5. Juvenile laminarians (A), Egregia laevigata (B), and Eisenia arborea (C). Recruitment of new individuals since prior census. Quadrat symbols: open squares, DS 1; open circles, DS 2; open triangles, DS 3; closed circles, BR 2; closed triangles, $\mathrm{BR} 3$; closed square, BR $4, \mathrm{x}, \mathrm{BR} 6$

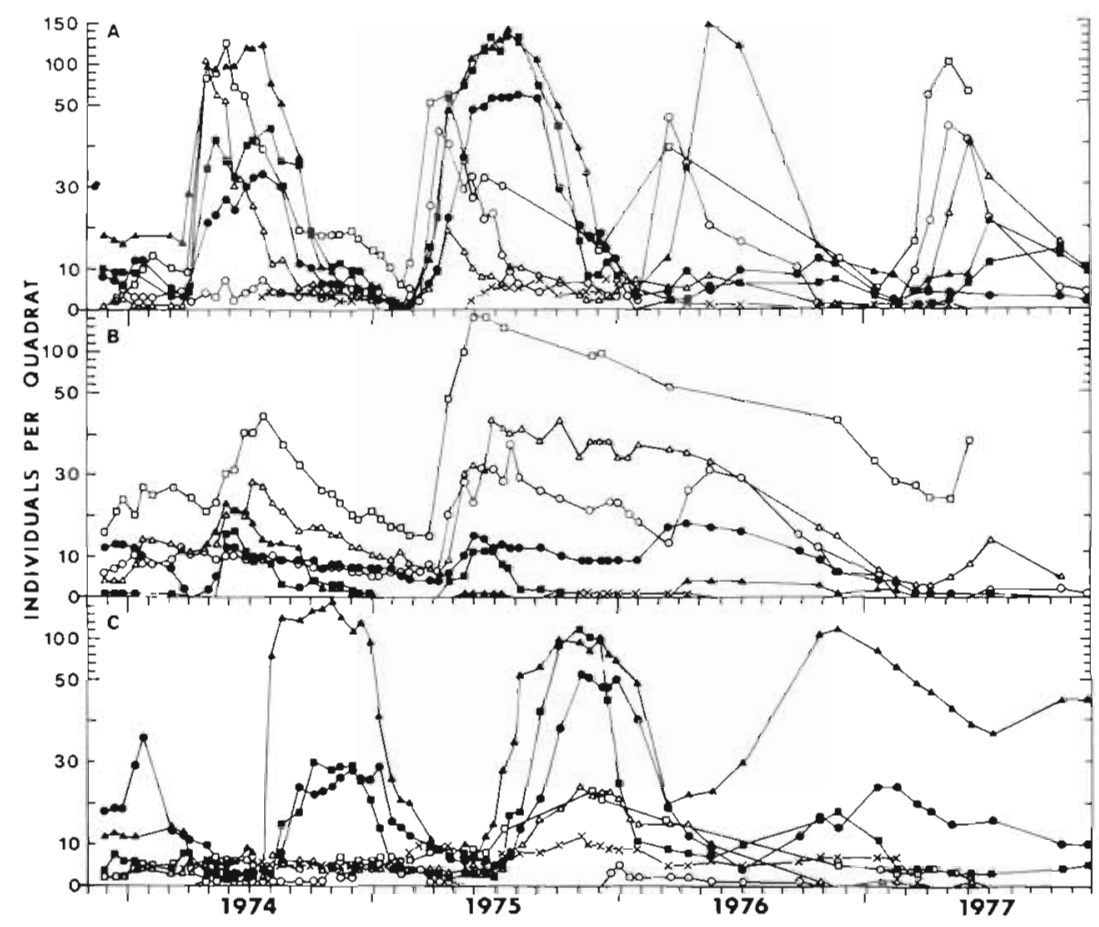

Fig. 6. Juvenile laminarians (A), Egregia laevigata (B), and Eisenia arborea (C). Standing stocks of individuals within survey quadrats. See legend to Figure 5 for quadrat symbols 
In Central California, Egregia laevigata sporophytes reproduced from November into the spring (Black, 1974; Luning and Neushul, 1978). At La Jolla, spring recruitment on rocks freshly bared in November indicated similar reproductive periods for both laminarian species. Recruitment recorded in the fall and winter generally resulted from the wave transport of stones bearing plants (Fig. 5). Juvenile sporophytes of $E$. laevigata emerged from February to May, but maximally in March and April. Eisenia arborea recruitment was generally greatest in late April and May and extended into July; this later recruitment caused the apparent delay of net recruitment by juvenile laminarians at BR (Fig. 5), because the relative abundances of juveniles reflected those of the adults.

Recruitment by juvenile laminarians generally was similar within years at the quadrats in each location (Fig. 5). Differences between years, however, were substantial. At least initially these differences were reflected in the standing stock records of juvenile and adult laminarians (Fig. 6).

Most adult specimens of Egregia laevigata at BR in 1973 were lost by April 1974, but were rapidly replaced by recruits (Figs 5 and 6 ). In contrast, recruitment was effective in only 2 quadrats at DS in 1974. Most 1974 recruits were lost by November 1974. While net recruitment was relatively low at BR in 1975, at DS juveniles recruiting either early or late matured into adults. Many 1975 recruits persisted into the following year, but few new adults grew in either study location during 1976. Net stock declines followed relatively normal initial recruitment and continued through the summer of 1976. Some adults from previous years remained at DS in 1977; juveniles did recruit but produced relatively few new adults. Quadrat populations in less abundantly occupied quadrats either fluctuated with those of other quadrats or disappeared entirely in 1976-1977.

Standing stocks of Eisenia arborea increased at BR in 1974 and at both locations in 1975 following prolonged recruitment and maturation periods (Figs 5 and 6). Although later maturing individuals did not overcome the annual standing stock decline in 1975, many individuals survived into the summer of 1976. In 1976 recruitment was reduced at BR (except in Quadrat 3) and was virtually absent at DS. The late emergence and maturation failure of few recruits led to few adults in 1977. Thus most individual of E. arborea present in 1977 (at BR 2 and BR 3) were adults from previous years which survived the die out in 1976.

\section{Environmental Factors}

Surface waters at La Jolla, California were warmest in July and August and generally coldest in January and February (Fig. 7A). Because of upwelling, daily spring-summer temperatures often were lower than those in the winter. Within years, temperature variability during the late spring and summer occurred around the regional monthly average surface water temperature (Chapman, 1962; S. Tont, pers. comm.). Some entire winters, however, were relatively cool (1974-1975) or warm (1976-1977). The timing of seasonal warming or cooling also differed between years.

Air temperatures at Scripps Pier were moderated by water temperatures and generally ranged from 10 to $20{ }^{\circ} \mathrm{C}$ (Fig. 7B). Occasionally warm desert winds (known locally as Santa Anna winds) with low humidity caused air temperatures to exceed $20^{\circ} \mathrm{C}$ at the pier. Although such winds were most common from September to November, they occurred in the last week of June in all years between 1973 and 1979 but 1975 and 1977. Typically, July through November were warm, while January, March and April were cool.

Regional tides were semi-diumal with a maximum range of -2 to $+7.6 \mathrm{ft}(-0.66$ to $+2.5 \mathrm{~m})$. Tidal

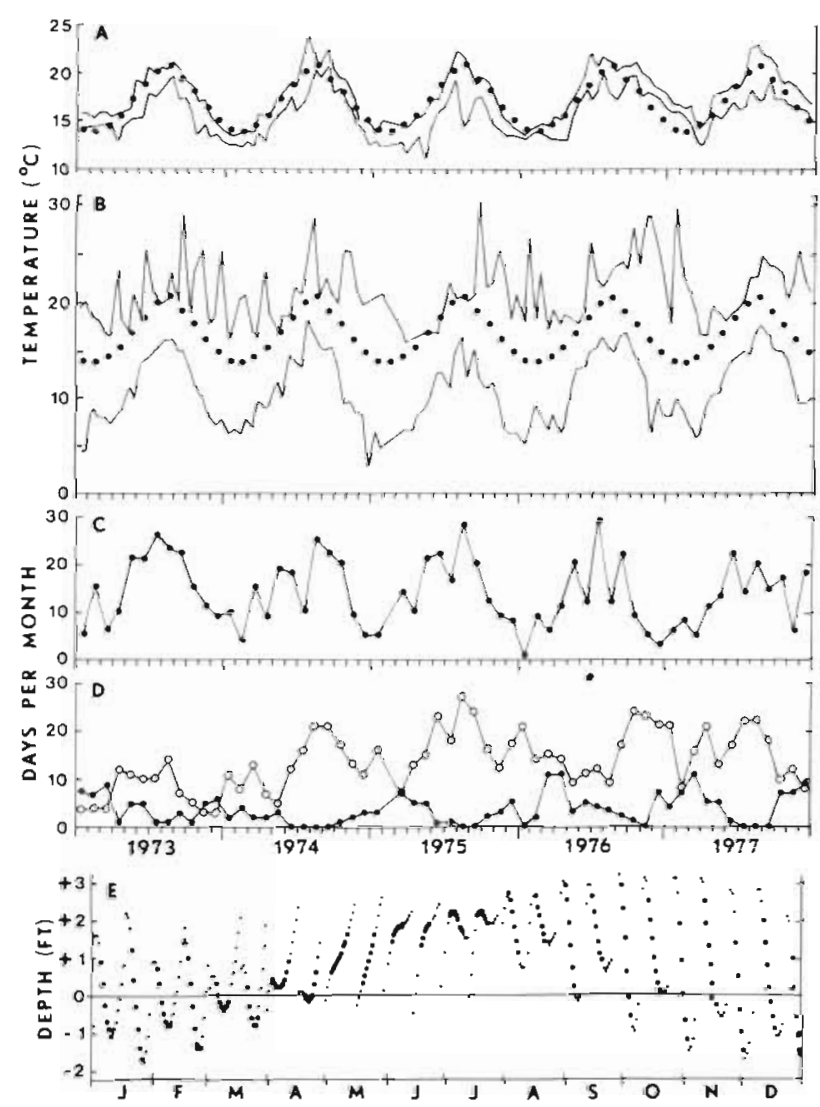

Fig. 7. Environmental factors. Water (A) and Air (B) temperature ranges during 2 week intervals. Solid circles are longterm monthly averages. (C) Monthly frequencies of cloud cover exceeding $90 \%$. (D) Monthly frequencies of swell height either $\geqslant 4 \mathrm{ft}(1.32 \mathrm{~m})$, closed circles; or, $\leqslant 1 \mathrm{ft}(0.33 \mathrm{~m})$, open circles. (E) Predicted depths of exposure by daytime low tides $(0600$ to $1800 \mathrm{~h})$; larger circles $=1000$ to $1700 \mathrm{~h}$ 
exposure patterns repeated between the years studied but were not uniform throughout the year, since the duration and timing of daytime exposure varied seasonally (Fig. 7E). At the $+3 \mathrm{ft}(+0.99 \mathrm{~m})$ tidal level, daytime exposure increased during September and October and was greatest between November and March. During the spring, daytime low tides occurred earlier in the day so as the transition to nighttime lower low tides was approached, periods of exposure were centered on $1200 \mathrm{~h}$. The $+1 \mathrm{ft}(+0.33 \mathrm{~m})$ level generally was not exposed by day during either the late spring or summer.

Cloud cover plus wave and swell heights varied seasonally, but were not highly predictable (Fig. 7C and D). Cloud cover was recorded between 0800 and $1000 \mathrm{~h}$, and may have differed at the time of low tides, for fogs in particular often cleared at least briefly at mid-day. Coastal fog was especially common in the spring and summer. Sunny days were most common between October and April and especially between October and February. Calm surf (1 to $3 \mathrm{ft} ; 0.33$ to $0.99 \mathrm{~m}$ ) predominated at La Jolla; calmer periods were most common between June and October, while heavier swell were more common between December and May. The first storms of winter typically arrived between November and January. In 1976 heavy swell $\left(\geqslant 4 \mathrm{ft}_{;} 1.32 \mathrm{~m}\right)$ started late and continued infrequently throughout the summer. Heavy swell patterns were similar in 1975 and 1977 and in both years were marked by episodes of $4 \mathrm{ft}(1.32 \mathrm{~m})$ swell scattered among frequent calm days in May.

Effects from the seasonal tide, cloud cover and storm patterns were seen directly in the coralline algaerhodophyte assemblages which cover much of the local intertidal area. With the onset of daytime tidal exposures in the fall, the assemblages died back over extensive areas. Partial recovery of the assemblages occurred during the winter and spring, but each stage may have been offset by new episodes of desiccation or disturbance (Emerson and Zedler, 1978; Gunnill, 1979). Diebacks were an annual event during this study, but their timing, extent and frequency differed between years.

\section{DISCUSSION}

Macroalgae are a major component of many nearshore communities, thus variations in their standing stocks would be significant to community structure (Dayton, 1971, 1975; Hruby, 1975; Lewis, 1977). During relatively long periods of study, natural standing stock variations have been recorded within populations of several macroalgae. Laminaria spp. indicated an 11year oscillation (Walker, 1956; Walker and Richardson,
1957) and populations of Macrocystis pyrifera have been well known for their fluctuations (North, 1971; Rosenthal et al., 1974). Several fucoid algae exhibited population bursts after long periods of absence or low abundance (Fischer-Piette and Duperier, 1960; Fischer-Piette and Lahondere, 1973). Such bursts occurred asynchronously between species of fucoid algae and between areas on the coasts of France.

Within a 4-year interval, in the present study and in Gunnill (1979), similar bursts and equally rapid declines produced net trends in the standing stocks of 6 perennial macroalgae. Standing stocks of Pelvetia fastigiata and Cystoseira osmundacea increased by bursts and those of Sargassum muticum increased progressively at many quadrats. Abundances of Codium fragile, Egregia laevigata and Eisenia arborea declined. The standing stock variations did not result from an environmental trend; instead, they were related to environmental variations during the reproduction and recruitment periods of the algae.

\section{Annual Reproduction and Recruitment}

The 7 algae surveyed at La Jolla have annual periods of reproduction and recruitment which tend to coincide. Seasonal reproduction and growth have often been attributed to individual environmental factors limiting or triggering growth. Such factors include light, temperature and nutrient availability (Conover, 1964; Edwards, 1969; Jackson, 1977) which can interact; for example, growth requirements are met within ranges of temperature and illumination (Hsaio and Drueh1, 1973; Lüning and Neushul, 1978). Zavodnik (1973) suggests that growth rhythms respond to light, but that the primary cause of variation is temperature.

Most species surveyed developed reproductive structures in the fall and early winter when day lengths and temperatures were decreasing and when light intensity was relatively high because of generally clear skies and lower low tides during the day. The species were responding to different environmental factors; Pelvetia fastigiata (Robinson and Cone, 1980) and Codium fragile (Hurd, 1916; Churchill and Moeller, 1972) reproduced at substantially different times in more northern locations, but Egregia laevigata (Black, 1974 ) did not. Light intensity and tidal exposure would be important to the intertidal $C$. fragile and $P$. fastigiata. Light intensity has been related to receptacle development by some fucoid algae (Ardré, 1969; Zavodnik, 1973) and, for Pelvetia spp., gamete release is facilitated by desiccation during tidal exposure (Subrahmanyan, 1957). Light intensity and hydrostatic pressure variations related to tidal patterns are also 
correlated with gamete release by Cystoseira spp. living in the low-intertidal and subtidal zones (Zaneveld, 1969). However, although closely related to Cystoseira spp., Halidrys dioica reproduced when skies are infrequently clear and, except at the end of its reproductive period, when tidal ranges are relatively small.

Although reproduction by several Sargassum spp. may be triggered by decreasing day lengths and water temperatures (Prince and O'Neal, 1979), S. muticum reproduces with increasing water temperatures and day lenghts: in La Jolla and in Southern England, this species reproduces when water temperatures exceed $15^{\circ} \mathrm{C}$ (Jephson and Gray, 1977). Individuals, however, must grow annual fronds before they can reproduce. Although $S$. muticum grow most rapidly in warm waters (Norton, 1977a), the annual fronds grow through the winter in relatively cold waters. Like $S$. pteropleuron (Prince and O'Neal, 1979), S. muticum grow their annual fronds and receptacles when nutrient concentrations are relatively high.

Most species had protracted recruitment periods, suggesting that once recruitment had begun conditions were generally favorable for growth. Within years, however, the onset of recruitment of each alga generally differed between quadrats at a location by less than a month and, except for Codium fragile, also coincided at the 2 locations. Thus each species was responding to similar factors at either location. Egregia laevigata sporophytes began to recruit as water temperatures began to rise in the spring, the time of recruitment differing between years with the timing of the annual temperature increase. The dominant feature co-occurring with algal recruitment at La Jolla, however, was a spring-summer combination of frequent cloud cover, increasing day length, reduced exposure to air and rising water temperatures with high variability indicative of upwelling. Sargassum muticum recruits emerged in the warmest waters of the year (see also Jephson and Gray, 1977). By the end of the summer embryos and/or juveniles of all species were growing in calm, warm and stratified waters.

Seasonality may be adaptive for reasons other than the presence of growth factors. Fall and early winter are periods of intense desiccation at La Jolla. Subsequently, increased cloud cover reduces desiccation, but storm swell becomes common from December into the spring. Both desiccation and water force can affect the standing crops and species compositions of algal assemblages (Jenik and Lawson, 1967; Doty, 1971; Santelices, 1977). Standing stocks of the algae surveyed commonly declined between October and March. All species could have been damaged by desiccation, but water force also is implicated because even subtidal individuals of the laminarians became common in winter drift debris.
Juvenile algae are often less resistant to desiccation than adults (Kristensen, 1968; Zaneveld, 1969); moreover, high surf would remove juvenile plants with developing holdfasts (e. g. Lewis, 1968). Therefore, both factors could limit recruitment periods at La Jolla. Only Pelvetia fastigiata commonly recruited new individuals throughout the year, although the numbers recruiting were relatively low in the fall and winterspring. No species predominantly recruited in the fall. Cystoseira osmundacea did recruit in the winter, but generally only in sheltered areas in the low-intertidal zone. Many species initiated recruitment in the spring when moderate swell were frequent, but only Egregia laevigata became relatively large before the calm seas of summer.

All 7 algae reproduced either at the beginning or the end of the local storm season when relatively vigorous water motion might be expected to disperse developmental stages and detached fertile plants (Anderson and North, 1967; Rosenthal et al., 1974; Norton, 1976). In addition, disturbance by surf would provide competitively important free space for embryos and recruits of all species (Dayton, 1971; Kain, 1975). The 7 algae, however, differed in the relative magnitude of their annual standing stock variations. Fall/winter reproduction would be particularly advantageous for species with relatively high losses among reproductive individuals during the fall and winter.

Egregia laevigata, Eisenia arborea and Codium fragile disappeared from some areas each year. E. laevigata was tactically an annual in intertidal areas in Central California where the sporophytes could reproduce within 8 months (Black, 1974). At La Jolla, both laminarians reproduced in the winter and, thus, some of the recruits should have been able to reproduce before they were lost. However, it is unclear if these species were functioning as annuals, because areas recolonized each year were near perennial individuals. Widely separated subpopulations of $C$. fragile, particularly those on mid-intertidal ridges, recurred annually, yet recruitment records indicated little long distance dispersal. Individuals smaller than those on the ridges can reproduce (Hurd, 1916); some individuals on the ridges blanched and thus probably did reproduce. Reproduction prior to seasonal losses would allow $C$. fragile to persist in some areas as self-sustaining subpopulations of small annual individuals and in other areas as dispersed long-lived individuals with low net recruitment.

Minor fluctuations occurred in the standing stocks of Cystoseira osmundacea plus Halidrys dioica when juveniles recruited concurrently with reproduction by older individuals. Pelvetia fastigiata reproduced after annual declines in standing stocks and the recruits did not reproduce until their second year of life. Again, 
reproduction was carried out by a relatively permanent standing stock of individuals that had recruited in previous years (Gunnill, 1979).

Sargassum muticum reproduced after annual losses of both juveniles and older individuals. Recruitment occurred at the end of the summer. Recruits exposed at higher intertidal levels died out each fall, while individuals persisted in pools and channels where slower drainage and water retained by sand and other algae would lessen desiccation and where plants were more protected from waves (Norton, 1977b). Although plants in low-intertidal channels could grow through the winter, those in shallow pools and mid-intertidal channels remained relatively short until spring. Jephson and Gray (1977) determined that damaged (and thus relatively short) plants did develop receptacles, but the net effects of growth variations with tidal level and topography on gamete production by the population are not known. However, S. muticum became most abundant where the plants remained relatively short.

\section{Between-Year Variations in Standing Stock}

Within years the standing stocks of each alga generally were similar at similar sites at both BR and DS; thus the differences between years were related to regional environmental factors. Temperature, water motion, desiccation and light intensities normally vary between as well as within years. In addition, the reproductive periods of algae have differed by as much as 2 months between locations in one area or between years in one location (Zavodnik, 1973; Edelstein and McLachlan, 1975). The reproduction and recruitment periods of the algae surveyed indicated similar variability. Thus, variations in either the intensity of environmental factors or the timing of the alga in relation to seasonal environmental variations could affect standing stocks.

Standing stocks of Pelvetia fastigiata and Cystoseira osmundacea increased in 1975 and especially 1977; those of C. osmundacea also increased substantially in 1974. For both species, individuals reproducing in 1977 included 1975 recruits. In both 1975 and 1977 relatively warm and sunny weather occurred during receptacle development. Ardré (1969) and Zavodnik (1973) related growth and maturation rates of fucoid algae to light and temperature; Fritch (1945 in Zaneveld, 1969) demonstrated accelerated gamete release by Cystoseira spp. with increasing light intensity. Both $C$, osmundacea and $P$. fastigiata may have reproduced relatively early in 1977 and $C$. osmundacea did so in 1974 suggesting that recruitment bursts were related to early reproduction. Although recruits of $C$. osmundacea should have originated in the previous year, plants germinating immediately after early reproduction could have recruited during the winter of the same year and thus added to other recruits. However, high recruitment was not solely related to early and/or high reproductive output. For example, the occurrence of many fertile individuals of $P$. fastigiata in January 1979 did not cause high recruitment. For $P$. fastigiata, high recruitment also correlated with winter-spring swell heights and with the absence of a brief period of desiccation following initial recruitment. Thus, for P. fastigiata and probably for C. osmundacea as well, the survival of embryos and juveniles also was important to net recruitment.

Standing stocks of Egregia laevigata and Eisenia arborea increased slightly in 1975 and then declined through 1976 and 1977. The initial increase occurred when individuals persisted through a winter with low to normal swell heights and below average water temperatures. The declines occurred when older individuals were lost and when recruitment was low. E. laevigata began to recruit as the waters warmed in 1976, and early recruits grew rapidly. The few later recruits, however, emerged directly into seasonally late storm swell. Many young plants were abraded and most failed to mature. Recruitment recorded for $E$. arborea in 1976 followed the heavy swell and was concentrated at 1 quadrat. Summer storm swell could have affected both species in 1976, but the plants tended to die during a 6 -month period of warm water. At this time, previously perennial individuals in permanent pools near and within the survey quadrats died out. E. laevigata did recruit in March 1977, as the water cooled. The late and low recruitment of $E$. arborea in 1977 followed sequences of moderate swell in May. Since recruitment was not inhibited by similar surf in May 1975, it appears that E. arborea was more sensitive to warm water than E. leavigata.

Standing stock patterns of Codium fragile in 1976 and 1977 resembled those of Egregia laevigata, suggesting that both species were affected by the same factors. However, over the 4-year interval, abundances of $C$. fragile were greatest when summers had many foggy days and smallest when late summers were warm and had few foggy days. Late summer fogs reducing desiccation would have been especially important at DS where recruitment occurred later than at $\mathrm{BR}$ and where from 1975 to 1977 annual standing stock increases occurred during daytime lower low tides. Intense desiccation occurred in the fall in all years and presumably was not the cause of the unusually low initial recruitment in 1976. Spring and especially summer swell in 1976 could have reduced recruitment by $C$. fragile, but net recruitment from 1975 to 1977 suggests that desiccation and/or temperatures at the time of recruitment were affecting stocks in subsequent years. 
Sargassum muticum is regarded as highly invasive since it has high growth rates and a marked capacity for regeneration, reproduction and dispersal (Fletcher and Fletcher, 1975; Norton, 1976; 1977b). At La Jolla, this alga not only reproduced after plants had been lost or damaged in the winter, but also as recruits of other species were growing and still colonized the study area. Much of the initial population increase of $S$. muticum, however, occurred in unstable mid-intertidal areas or high intertidal pools which were not occupied or consistently occupied by other macroalgae (see also Jephson and Gray, 1977). In 1976 and 1977, this species colonized several low-intertidal rocks formerly occupied by laminarians when recruits grew in free space temporally or spatially free of the laminarians. In addition, $S$. muticum often recruited in disturbed portions of surf grass beds. Once established in such areas, $S$. muticum was perennial. In general abundances of $S$. muticum were relatively stable, even while those of other species were fluctuating.

Since all 7 algae examined at La Jolla were perennials, persistent individuals could live through years with low recruitment. In addition, relatively long periods of reproduction and recruitment would lessen the risk of all individuals developing under unfavorable conditions. Nevertheless, there were substantial between-year standing stock variations. Years with high recruitment, such as occurred for Pelvetia fastigiata, could cause the population explosions reported for fucoid algae in other parts of the world (FischerPiette and Duperier, 1960). Low recruitment plus the loss of adults would led to the absence of Egregia laevigata in intertidal areas observed by Chapman (1962) and certainly repetition of the conditions causing such losses would reduce subtidal populations of both laminarians. Most importantly, there were no environmental trends during this study; the algae were responding independently to normal variations in the timing and/or intensity of seasonal environmental factors. No single environmental factor accounted for all between-year stock variation and no species was apparently affected by a single factor in all years.

Acknowledgements. I thank J. Cullen, P. Dayton and G Jackson for comments on preliminary drafts; T. Gerrodette, L. Gunnill and $G$. van Blaricom for field assistance; and $L$. Gunnill for helping to compile the data. I am grateful to the staff of Scripps Aquarium for obtaining and F. Wilkes (D.C.P.G.) for providing environmental records. This research was partially supported by Sea Grant and N.S.F. Dissertation Improvement Grant funding.

\section{LITERATURE CITED}

Abbott, I. A., North, W. J. (1971). Temperature influences on floral composition in California coastal waters. Int. Seaweed Symp. 7: 72-79

Anderson, E. K., North, W. J. (1967). In situ studies of spore production and dispersal in the giant kelp, Macrocystis. Int. Seaweed Symp. 5: 73-86

Anonymous (1975). Tide tables, high and low water predictions West Coast of North America including the Hawailan Islands, 1975, U.S. Coast and Geodetic Survey, Washington, DC

Ardré, F. (1969). Remarques sur le Pelvetia canaliculata (L.) Dec. et Thur. Int. Seaweed Symp. 6: 31-40

Bellamy, D. F., Bellamy, R., John, D. M., Whittick, A. (1967). Some effects of pollution and rooted marine macrophytes on the north-east coast of England. Br. phycol. Bull. 3: 409

Black, R. (1974). Some biological interactions affecting intertidal populations of the kelp Egregia laevigata. Mar. Biol. 28: 189-198

Boalch, G. T., Holme, N. A., Jephson, N. A., Sidwell, J. M. C. (1974). A resurvey of Colman's intertidal traverses at Wembury, South Devon. J. mar. biol. Ass. U. K. 54: $551-553$

Chapman, A. R. O. (1979). Biology of Seaweeds: Levels of Organization, University Park Press, Baltimore, Maryland

Chapman, V. J. (1962). A contribution to the ecology of Egregia laevigata Setchell, 3. Photosynthesis and respiration: Conclusions. Botanica. Mar. 4: 101-122

Churchill, A. C., Moeller, H. W. (1972). Seasonal patterns of reproduction in New York populations of Codium fragile (Sur.) Hariot subsp. tomentosoides (van Goor) Silva. J. Phycol. 8: 147-152

Conover, J. T. (1964). The ecology, seasonal periodicity, and distribution of benthic plants in some Texas lagoons. Botanica Mar. 7: 4-41

Dayton, P. K. (1971). Competition, disturbance, and community organization: the provision and subsequent utilization of space in a rocky intertidal community. Ecol. Monogr. 41: $351-389$

Dayton, P. K. (1975). Experimental evaluation of ecological dominance in a rocky intertidal algal community. Ecol. Monogr 45: 137-169

Doty, M. S. (1971). Antecedent events influence on benthic marine algal standing crops in Hawaii. J. exp. mar. Biol. Ecol. 6: 161-166

Edelstein, T., McLachlan, J. (1975). Autecology of Fucus distichus spp. distichus (Phaeophyceae: Fucales) in Nova Scotia, Canada. Mar. Biol. 30: 305-324

Edwards, P. (1969). Field and cultural studies on the seasonal periodicity of growth and reproduction of selected Texas benthic marine algae. Contr. mar. Sci. 14: 59-114

Emerson, S. E., Zedler, J. B. (1978). Recolonization of intertidal algae: an experimental study. Mar. Biol. 44: 315-324

Fischer-Piette, E., Dupérier, R. (1960). Variations des fucacées de la cote Basque, de 1894 à 1959. Bull. Cent. Etud. Rech. scient., Biarritz 3: 67-90

Fischer-Piette, E., Lahondere, C. (1973). Evolutions récentes de populations de fucacées de nos cotes sud-ouest. Botaniste 56: 5-17

Fletcher, R. F., Fletcher, S. M. (1975). Studies on the recently introduced brown alga Sargassum muticum (Yendo) Fensholt I. Ecology and reproduction. Botanica Mar. 18: 149-156

Gardner, N. I. (1913). New Fucaceae. Univ. Calif. Publs Bot. 4 $317-374$ 
Gunnill, F. C. (1979). The Effect of Host Distribution of the Faunas Inhabiting an Intertidal Alga. Ph. D. Dissertation, University of California, San Diego

Hruby, T. (1975). Seasonal changes in two algal populations from the coastal waters of Washington State. J. Ecol. 63: 881-889

Hsiao, S. I. O., Druehl, L. D. (1973). Environmental control of gametogenesis in Laminaria saccharina, IV in situ development of gametophytes and young sporophytes. J. Phycol. 9: 160-164

Hurd, A. M. (1916). Codium mucronatum. Publs Puget Sound mar. biol. Stn 1: 109-123

Jackson, G. A. (1977). Nutrients and production of giant kelp, Macrocystis pyrifera, off southern California. Limnol. Oceanogr. 22: 979-995

Jenik, J., Lawson, G. W. (1967). Observations on water loss of seaweeds in relation to microclimate on a tropical shore (Ghana). J. Phycol. 3: 113-116

Jephson, N. A., Gray, P. W. G. (1977). Aspects of the ecology of Sargassum muticum (Yendo) Fensholt, in the Solent region of the British Isles. I. The growth cycle and epiphytes. In: Keegan, B. F., Ceidigh, P. O., Boaden, P. J. S. (eds) Biology of benthic organisms. Pergamon Press, Oxford, pp. $367-375$

Kain, J. M. (1975). The biology of Laminaria hyperborea, VII. Reproduction of the sporophyte. J. mar. biol. Ass., U. K. 55: $567-582$

Kristensen, I. (1968). Surf influence on the thallus of fucoids and the rate of desiccation. Sarsia 34:69-82

Lewis, J. R. (1968). Water movements and their role in rocky shore ecology. Sarsia 34: 13-36

Lewis, J. R. (1977). The role of physical and biological factors in the distribution and stability of rocky shore communities. In: Keegan, B. F., Ceidigh, P. O., Boaden, P. J. S. (eds) Biology of benthic organisms. Pergamon Press, Oxford, pp. $417-423$

Lüning, K., Neushul, M. (1978). Light and temperature demands for growth and reproduction of laminarian gametophytes in Southern and Central California. Mar. Biol. 45: 297-309

Moss, B., Lacey, A. (1963). The development of Halidrys siliquosa (L) Lynqb. New Phytol. 62: 67-74

Moss, B., Sheader, A. (1973). The effect of light and temperature upon the germination and growth of Halidrys siliquosa (L) Lynqb. (Phaeophyceae, Fucales). Phycologia, 12: $63-68$

Neushul, M. (1972). Functional interpretation of benthic marine algal morphology. In: Abbott, I. A., Kurogi, A. (eds)
Contributions to the systematics of benthic marine algae of the North Pacific. Japan Society for Phycologia, Tokyo, pp. $47-73$

North, W. J. (1971). Introduction and background. In: North, W. J. (ed.) The biology of giant kelp beds (Macrocystis) in California. Beihefte zur Nova Hedwigia 32 (Suppl.): 1-67

Norton, T. A. (1976). Why's Sargassum muticum so invasive? Br. Phycol. J. 11: 197-198

Norton, T. A. (1977a). The growth and development of Sargassum muticum (Yendo) Fensholt. J. exp. mar. Biol. Ecol. 28: $41-53$

Norton, T. A. (1977b). Ecological experiments with Sargassum muticum. J. mar. biol. Ass. U. K. 57: 33-43

Prince, J. S., O'Neal, S. W. (1979). The ecology of Sargassum pteropleuron Grunow (Phaeophyceae, Fucales) in the waters off South Florida. I. Growth, reproduction and population structure. Phycologia 18: 109-114

Robinson, K. R., Cone, R. (1980). Polarization of fucoid eggs by a calcium ionophore gradient. Science, N. Y. 207: $77-78$

Rosenthal, R. J., Clarke, W. D., Dayton, P. K. (1974). Ecology and natural history of a stand of giant kelp, Macrocystis pyrifera, off Del Mar, California. Fish. Bull. U.S. 72 : $670-684$

Santelices, B. (1977). Water movement and seasonal algal growth in Hawaii. Mar Biol. 43: 225-235

Subrahmanyan, R. (1957). Observations of the anatomy, cytology, development of the reproductive structures, fertilization and embryology of Pelvetia canaliculata Dene, et Thur. III. The liberation of reproductive bodies fertilization and embryology. J. Indian bot. Soc. 36: 378-395

Walker, F. T (1956). Periodicity of the Laminariaceae around Scotland. Nature, Lond. 177: 1246

Walker, F. T., Richardson, W. D. (1957). Survey of the Laminariaceae off the Island of Arran: Changes from 1952 to 1955. J. Ecol . 45: 225-232

Widdowson, T. B. (1971). Changes in the intertidal algal flora of the Los Angeles area since the survey by $E$. Yale Dawson in 1956-1969. Bull. Sth. Calif. Acad. Sci. 70: 2-16

Wilkinson, M., Tittley, I. (1979). The marine algae of Elie, Scotland: a Re-assessment. Botanica Mar. 22: 249-256

Zaneveld, J. S. (1969). Factors controlling the delimitation of littoral benthic marine algal zonation. Am. Zool. 9: 367-391

Zavodnik, N. (1973). Seasonal variations in rate of photosynthetic and chemical composition of the littoral seaweeds common to North Adriatic, Part 1, Fucus virsoides (Don) J. Ag. Botanica Mar. 16: 155-165 